In the 60 infants reported here the mean serum bilirubin on admission was within the normal range $(0.82 \mathrm{mg} . / 100 \mathrm{ml}$.) and the initial reticulocyte count was usually only slightly raised (mean 3\%), both values being little higher than corresponding control means of $0.54 \mathrm{mg} . / 100 \mathrm{ml}$. and $1.6 \%$. For this reason it seemed unlikely that the anaemia was predominantly haemolytic. When temporary marrow hypoplasia occurs, however, it does not affect the haemoglobin appreciably unless the red cell survival time is considerably reduced, which has been shown by Hoffenberg (1967, personal communication) to be the case in kwashiorkor. A haemolytic element should therefore be added to the factors which may contribute to the anaemia in this disease, though its impontance remains to be clarified.

\section{Iron and Folic Acid as Supplements During Treatment}

We previously demonstrated (Adams and Scragg, 1965) that iron deficiency may occur in the recovery phase of kwashiorkor and we have now shown that it can be prevented by administration of iron. Since the detection of iron deficiency with any degree of certainty may require sophisticated tests which are not practicable except as research procedures, we recommend the administration of intramuscular iron to all infants with this disease, a total of $9 \mathrm{ml}$. of iron dextran being given over the first two weeks. In view of the high propontion of controls who appeared to be iron-deficient, judged on plasma iron patterns, it may well be that the occurrence of iron deficiency in kwashiorkor is not related to the disease itself but to the general iron status of infants in the age group at risk.

The case for supplements of folic acid is less easy to substantiate. It has been seen that partial megaloblastic erythropoiesis and subnormal serum folate levels are not uncommon findings on admission. Though they do not appear to limit haematological progress over the first four weeks, their existence can hardly be regarded with complacency. We have incomplete information about their long-term effects, but occasionally have observed the full picture of megaloblastic anaemia emerging later on. We therefore believe that the addition of folic acid to protein feeding is sound therapy in kwashiorkor, and recommend a routine supplement of $5 \mathrm{mg}$. thrice daily in all cases.

\section{Summary}

From a controlled clinical trial evidence is submitted in favour of the addition of iron to treatment with high-protein diet in kwashiorkor. Though iron-deficiency anaemia is seldom present on the patient's admission, routine treatment with iron prevents its development during the recovery phase.

No evidence was found that vitamin- $B_{12}$ deficiency plays a part in the production of anaemia in kwashiorkor, and there was little support for the view that its severity may be related to the presence of infection, though this complication undoubtedly affects prognosis adversely.

Partial megaloblastic erythropoiesis and folate deficiency are shown to be common findings without playing a major part in the aetiology of the anaemia. Nevertheless, reasons are given justifying the use of folic acid supplements in all cases.

The common haematological pattern during recovery from kwashiorkor, no matter whether haematinics are added or not, suggests that protein deficiency is the main cause of the anaemia.

We thank Professor H. L. Wallace for access to patients under his care and for helpful criticism, and the Medical Superintendent, King Edward VIII Hospital, for facilities. The work was supported by a grant from the Council for Scientific and Industrial Research.

\section{REPERENCES}

Adams, E. B. (1954). Brit. med. f., 1, 537.

— and Scragg, J. N. (1962). F. Pediat., 60, 580.

- (1965). Brit. 7. Haemat., 11, 676.

Allen, D. M., and Dean, R. F. A. (1965). Trans. roy. Soc. trop. Med. Hyg., 59, 326.

Bethard, W. F., Wissler, R. W., Thompson, J. S., Schroeder, M. A., and Robson, M. J. (1958). Blood, 13, 216.

Cartwright, G. E. (1947). Ibid., 2, 111.

Cronje, R. E., Savage, D. J., and Theron, J. J. (1961). Proc. Nutr. Soc. Sth. Afr., 2, 27.

Gritis, J., Piazuelo, E., and Vitale, J. J. (1963a). Amer. F. clin. Nutr., $12,452$.

Velez, H., Linares, F., Sinisterra, L., and Vitale, J. J. (1963b). Ibid., 12, 445.

Herbert, V. (1962). Trans. Ass. Amer. Phycns, 75, 307.

- (1966). F. clin. Path., 19, 12.

Lane, M., and Alfrey, C. P. (1965). Blood, 25, 432.

Lien-Keng, K., and Tumbelaka, W. A. F. J. (1960). Ann. paediat. (Basel), 194, 257.

Majaj, A. S., Dinning, J. S., Azzam, S. A., and Darby, W. J. (1963).

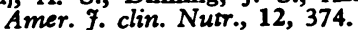

Marvin, H. N., and Audu, I. S. (1964). W. Afr. med. F., 13, 3.

Neame, P. B., and Simpson, J. C. (1964). S. Afr. F. Lab. clin. Med., 10, 27.

Sandstead, H. H., et al. (1965). Amer. F. clin. Nutr., 17, 27.

Sood, S. K., Deo, M. G., and Ramalingaswami, V. (1965). Blood, 26, 421.

Waters, A. H., and Mollin, D. L. (1961). F. clin. Path., 14, 335.

\title{
The Liver after Kwashiorkor*
}

\section{G. C. COOK, $†$ M.D., B.SC., M.R.C.P. ; M. S. R. HUTT, $\ddagger$ M.D., F.R.C.P., F.C.r̈ATH.}

In many tropical areas a widespread belief persists that malnutrition in infancy often predisposes to hepatic cirrhosis. Evidence has been put forward for a progression from the fatty liver of kwashiorkor (Trowell et al., 1954) to the development of cirrhosis (Davies, 1948 ; Ramalingaswami, 1964). There is a considerable weight of opinion against such a course of events in man (Gillman and Gillman, 1951 ; Higginson et al., 1957 ; Waterlow and Bras, 1957; Brock, 1966). This last view is, however, supported by only one adequate long-term follow-up

\footnotetext{
* From the Mulago Hospital and the Medical Research Council's Malnutrition Unit, Kampala, Uganda.

+ Lecturer in Medicine, Makerere University College, Kampala, Uganda $\ddagger$ Professor of Pathology, Makerere University College, Kampala,
} Uganda. investigation, which included liver histology (Suckling and Campbell, 1957). In that study, which was carried out in a non-tropical country-South Africa-there was no evidence of cirrhosis in liver biopsy specimens obtained from 20 children five years after recovery from kwashiorkor.

The present investigation was designed to study liver structure and function in 50 African children four years or more after they had had kwashiorkor.

\section{Patients and Methods}

Details of the 50 patients investigated are given in Table I. Fifty-five households were visited, but five children were found 
TABLE I.-Details of Children Investigated After Recovery From Kwashiorkor

\begin{tabular}{|c|c|c|c|c|c|c|c|}
\hline \multirow{2}{*}{$\begin{array}{l}\text { No. } \\
\text { Studied }\end{array}$} & \multicolumn{2}{|c|}{ Sex } & \multirow{2}{*}{$\begin{array}{c}\text { Age at } \\
\text { Diagmosis of } \\
\text { Kwashiorkor (yr) } \\
\text { (Mean and Range) }\end{array}$} & \multirow{2}{*}{$\begin{array}{c}\text { Length of Time } \\
\text { between Kwashiorkor } \\
\text { and Present Study (yr) } \\
\text { (Mean and Range) }\end{array}$} & \multirow{2}{*}{$\begin{array}{c}\text { Present Age (yr) } \\
\text { (Mean and Range) }\end{array}$} & \multirow{2}{*}{$\begin{array}{l}\text { Present Body Weight (kg.) } \\
\text { Expressed as Percentage of } \\
\text { Standard* for Same Age } \\
\text { (Mean and Range) }\end{array}$} & \multirow{2}{*}{$\begin{array}{l}\text { Present Height (cm.) } \\
\text { Expressed as Percentage of } \\
\text { Standard* for Same Age } \\
\text { (Mean and Range) }\end{array}$} \\
\hline & $\mathbf{M}$ & $\mathbf{F}$ & & & & & \\
\hline 50 & 29 & 21 & $1.8(0.7-4.7)$ & $7 \cdot 0(4 \cdot 0-11 \cdot 3)$ & $8 \cdot 8(5 \cdot 5-13 \cdot 0)$ & $82.3(56.9-99.5)$ & $92 \cdot 1(81 \cdot 4-101 \cdot 0)$ \\
\hline
\end{tabular}

to have died since the first admission: in no case did the history preceding death suggest that severe liver disease had been responsible. Eighteen of the children had been studied in an investigation of the jejunum after recovery from kwashiorkor (Cook and Lee, 1966). All of the 50 children lived within a 60 -mile $(96-\mathrm{km}$.) radius of Kampala. They had all been inpatients with kwashiorkor at the M.R.C. Malnutrition Unit, and good case-notes of the previous admission were available. They were taken at random from the admission register of children who left the unit alive. Of the 50 children 33 were from the local Baganda tribe, 14 from the Bahutu tribe of Rwanda, and 3 from other tribes. The severity of the preceding kwashiorkor was divided into four grades on clinical and laboratory criteria (Dean, 1960). Two had had very severe, 30 severe, 14 moderately severe, and 4 mild kwashiorkor.

They were readmitted to the Mulago Hospital for the present follow-up study. Details of the investigation were explained to the parents before the children were admitted. Though there was no evidence of severe malnutrition or vitamin deficiency in any of the children, most had some long-term sequelae of their kwashiorkor, for the mean weights and heights were reduced when compared with standard data for well-nourished Baganda schoolgirls. Weights were reduced more than heights (Table I); the correlation coefficient ( $r$ ) between individual weights (kg.) and heights $(\mathrm{cm}$.) in the 50 children was +0.893 . Twenty-three of the children had also been studied in an investigation which revealed that intravenous glucose tolerance was impaired in most of them (Cook, 1967a), probably owing to pancreatic insufficiency (Cook, 1967b). Three patients had sickle-cell disease and four had the sickle-cell trait. One child had a congenital dislocation of the right hip. Another had had paralytic poliomyelitis since his earlier admission. Parotid enlargement was present in 11 children, slight hepatomegaly in 11, and splenomegaly in 15 (gross in 7). Twentyone children had hepatomegaly and/or splenomegaly. There was no other clinical evidence of hepatocellular disease in any of the children. Four children with splenomegaly had a strongly positive, and one a positive, fluorescent malarial antibody titre (Voller and Bray, 1962) (Table II). A titre of $1: 1,600$ was taken to be strongly positive, and one of $1: 800$ to be positive.

TABLE II.-Serum Fluorescent Malarial Antibody Titres in Children

\begin{tabular}{|c|c|c|c|c|c|}
\hline \multirow{2}{*}{$\begin{array}{c}\text { No. } \\
\text { Examined }\end{array}$} & \multicolumn{5}{|c|}{ Serum Dilution* } \\
\hline & $\begin{aligned} & 1: 100 \text { or } \\
&<1: 100\end{aligned}$ & $\begin{array}{l}1: 200 \text { or } \\
>1: 200\end{array}$ & $\begin{array}{c}1: 400 \text { or } \\
>1: 400\end{array}$ & $\begin{array}{l}1: 800 \text { or } \\
>1: 800\end{array}$ & $\begin{array}{l}1: 1,600 \text { or } \\
>1: 1,600\end{array}$ \\
\hline 50 & 26 & 2 & 8 & 5 & 9 \\
\hline
\end{tabular}

Haemoglobin (Table III) and total and differential white cell count were done in all of the children. Total count was normal in all except five: four had a leucocytosis and one a leucopenia. Twenty-seven had an eosinophilia, accompanied in seven by a neutropenia. Serum bilirubin, aspartate and alanine aminotransferase, and alkaline phosphatase were estimated in all. Total plasma-protein, amino-acid ratio, and hydroxyproline index (Whitehead, 1964, 1965) were also measured (Table III). Three had an abnormality in both the amino-acid ratio and the hydroxyproline index. Brucella agglutinins were estimated in five patients who had granulomata in the liver biopsy specimens. Chest $x$-ray films and straight $x$-ray films of the abdomen were taken in all of the children. The heart shadow was normal in every one; four had pulmonary consolidation (three in the right upper lobe and one in the lingula), and one had bilateral hilar lymphadenopathy. No child had pancreatic calcification.

TABLE III.-Haemoglobin and Biochemical Tests of Nutritional Status in Children After Kwaskiorkor

\begin{tabular}{|c|c|c|c|c|c|c|c|}
\hline \multirow[t]{2}{*}{$\begin{array}{l}\text { No. } \\
\text { Tested }\end{array}$} & \multirow{2}{*}{\begin{tabular}{|c|} 
Haemo- \\
globin \\
(g. $/$ \\
$100 \mathrm{ml})$. \\
(Mean \\
and \\
Range) \\
\end{tabular}} & \multicolumn{2}{|c|}{$\begin{array}{c}\text { Total } \\
\text { Plasma-protein* } \\
(\mathrm{g} . / 100 \mathrm{ml} .)\end{array}$} & \multicolumn{2}{|c|}{ Amino-acid Ratio $\nmid$} & \multicolumn{2}{|c|}{$\begin{array}{l}\text { Hydroxyproline } \\
\text { Index } \neq\end{array}$} \\
\hline & & $\begin{array}{l}\text { Mean } \\
\text { and } \\
\text { Range }\end{array}$ & $\begin{array}{c}\text { No. } \\
\text { Abnor- } \\
\text { mal }\end{array}$ & $\begin{array}{l}\text { Mean } \\
\text { and } \\
\text { Range }\end{array}$ & $\underset{\substack{\text { No. } \\
\text { Abnor- } \\
\text { mal }}}{ }$ & $\begin{array}{c}\text { Mean } \\
\text { and } \\
\text { Range }\end{array}$ & $\begin{array}{c}\text { No. } \\
\text { Abnor- } \\
\text { mal }\end{array}$ \\
\hline 50 & $\begin{array}{l}12 \cdot 1 \\
(7 \cdot 1- \\
16 \cdot 0)\end{array}$ & $\begin{array}{c}7 \cdot 4 \\
(6 \cdot 0-9 \cdot 4)\end{array}$ & 12 & $\begin{array}{c}2 \cdot 1 \\
(1 \cdot 1-3 \cdot 7)\end{array}$ & 8 & $\left(\begin{array}{c}2 \cdot 9 \\
(0.8-5 \cdot 9)\end{array}\right.$ & 12 \\
\hline
\end{tabular}

Aspiration liver biopsies were obtained by an anterior subcostal approach under local anaesthesia with a $1.9-\mathrm{mm}$. Menghini needle (Menghini, 1958). We believe that this investigation was justified ; for in Uganda a considerable proportion of liver biopsy specimens from paediatric patients reveal a treatable disease-such as tuberculosis or schistosomiasis. Indeed, during the present study two cases of active tuberculosis were diagnosed as a result of liver biopsy. There were no complications. All the biopsy specimens were adequate for histological assessment, and all except four were between 1 and $4 \mathrm{~cm}$. in length. They were immediately fixed in $10 \%$ formol-saline solution and embedded in paraffin wax. Sections were cut at 5-7 $\mu$. They were stained with haematoxylin and eosin, a reticulin stain, and by Perls's technique for free iron The presence of malarial pigment was confirmed by demonstrating double refractility under polarized light. All biopsy specimens were examined on several occasions by both authors, and were compared with biopsies from six European children of mean age 10.3 (range 8 to 13 ) years who had no evidence of liver disease, and who had never lived in a tropical area. All six children had presented with symptoms and signs suggesting liver disease; in three the final diagnosis was extrahepatic venous obstruction, in one Gilbert's disease, and in the other two no conclusive diagnosis was reached, but liver disease was considered to have been excluded.

\section{Results}

\section{Liver Histology}

Table IV summarizes the results. No evidence of cirrhosis was found in any of the biopsy specimens. None of the abnormalities present in the specimens could be associated with any of the different tribes.

Twenty-one biopsy specimens were relatively normal when compared with the specimens from the six European children

TABLE IV.-Summary of Histological Findings in Liver Biopsy Specimens from Children After Kwashiorkor

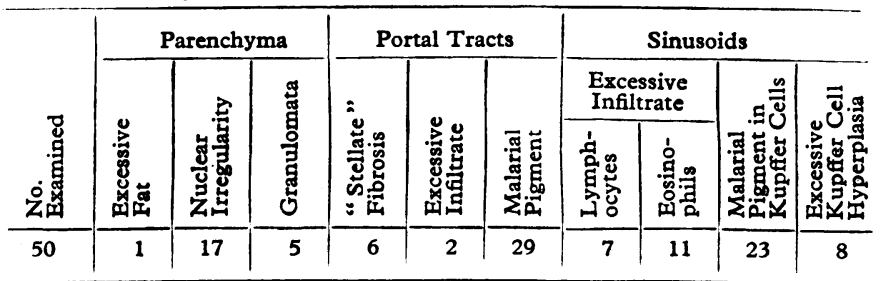


who had never lived in tropical areas. Most of these, however, had mild periportal fibrosis and/or portal infiltration with lymphocytes, and others had, in addition, occasional plasma cells and eosinophils in the portal areas. These changes were not severe enough, however, to produce expansion of the portal tracts. Most specimens showed slight Kupffer-cell hyperplasia and/or hypertrophy, and some showed a slight increase in sinusoidal lymphocytes. Apart from these changes, and the presence of some malarial pigment, nothing else abnormal was found.

The other 29 biopsy specimens showed similar changes, but all of these also had more striking abnormalities when compared with the European children.

\section{Parenchymal Cells}

In one biopsy specimen which also had "stellate" fibrosis radiating from the portal areas there was an excess of fat in the parenchymal cells (Fig. 1). That child had had very severe kwashiorkor, and both biochemical tests of current nutritional status were abnormal. Variability in nuclear size and staining with occasional double nuclei was present in 17 biopsy specimens; in 10 there was marked focal nuclear vacuolation. Nuclear vacuolation was also noted in two of the European specimens. Nuclear irregularity was present in one biopsy specimen which also showed "stellate" fibrosis. There was no association between the presence of nuclear irregularity and the severity of the preceding kwashiorkor. No evidence of cell necrosis in any biopsy specimen was found. Of the 17 with nuclear irregularity, five had lowered plasma proteins and five had an abnormality in one of the biochemical tests of current nutrition.

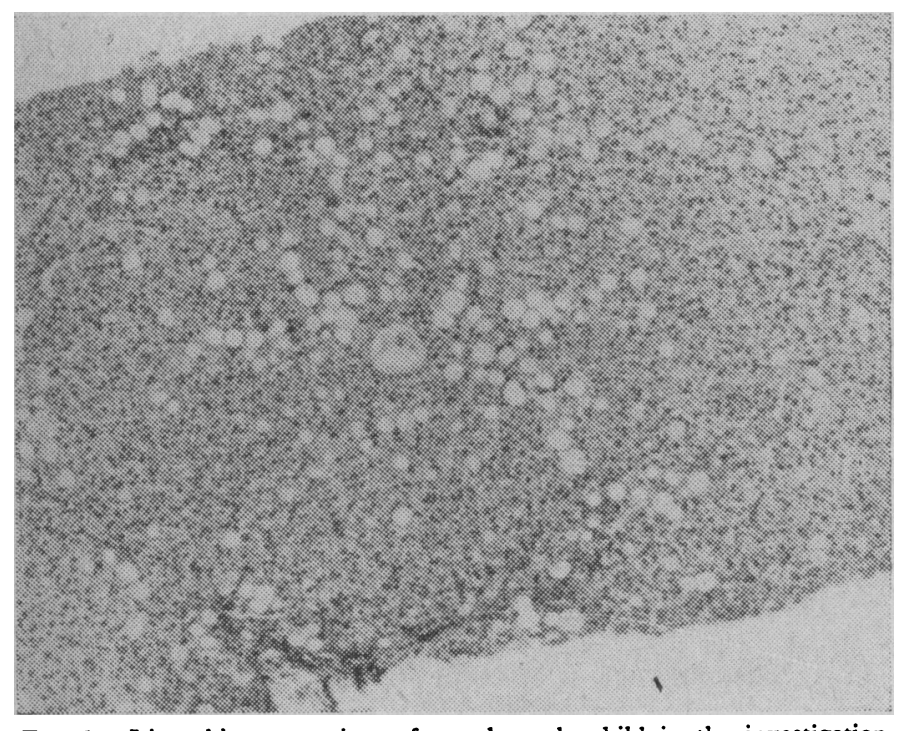

FIG. 1.-Liver biopsy specimen from the only child in the investigation to show an excess of fat in the parenchymal cells. (H. and E. $\times 20$.)

\section{Portal Tracts}

Stellate fibrosis spreading from more than one portal tract was found in six biopsy specimens (Fig. 2); one was from a very severe, four from severe, and one from a moderately severe case of kwashiorkor. These six patients had first been admitted between 1.1 and 2.7 (mean 1.7) years of age, and the time between treatment and follow-up was from 5.5 to 8.5 (mean 6.4) years. Three of these cases had an abnormality in one of the biochemical tests of current nutrition (one of them in both tests). In no case was there any widespread linking of the fibrous tissue between adjacent tracts. In several other biopsy specimens a distinct increase in fibrous tissue was present when compared with the controls, but was confined to the tracts.
Excessive infiltration with round cells, mainly lymphocytes, causing marked enlargement of several tracts was seen in two specimens.

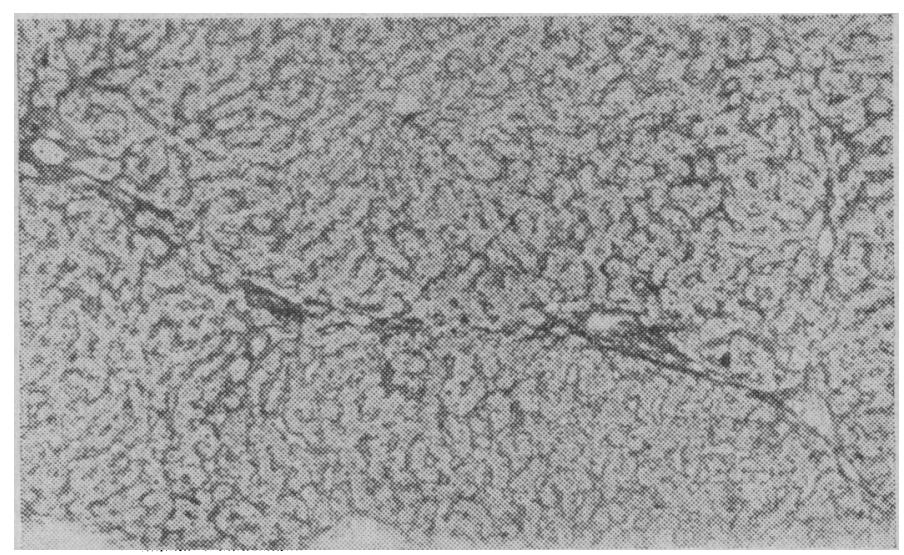

FIG. 2.-Liver biopsy specimen from one of the six children showing "stellate" fibrosis radiating from the portal areas. This specimen showed the most severe change in the present investigation. (Reticulin
stain. $\times 20$.)

\section{Sinusoids}

In seven specimens sinusoidal lymphocytes were greatly increased in number; four of these cases had splenomegaly and three, moreover, had a strongly positive malarial antibody titre. Malarial pigment was present in five of those seven biopsy specimens. Nine of the 11 specimens with an increase in sinusoidal eosinophils had a high eosinophil count in the peripheral blood. In eight specimens Kupffer cells were greatly enlarged and increased in number; three of these cases had a strongly positive malarial antibody titre.

Malarial pigment was present in the Kupffer cells or in the portal areas of 29 biopsy specimens (Table IV). There was none in the specimens from the children with sickle-cell disease. Twelve children with malarial pigment in the biopsy specimen had splenomegaly. The malarial antibody titre was strongly positive in five and positive in three of these. An excess of free iron in the Kupffer cells was seen in one specimen, from a patient with sickle-cell disease. "Granulomata" were seen in the parenchyma in five biopsy specimens. One was a classical epithelioid granuloma; this case and one other with a granuloma had consolidation of the right upper lobe which was due to tuberculosis. In four cases the "granulomata" consisted of small collections of chronic inflammatory cells grouped around a focus of degenerated parenchymal cells. The possibility that these represent schistosomal granulomata was considered, but ova were not demonstrated on serial sectioning. None of these patients showed a raised brucella antibody titre.

\section{Biochemical Tests of Liver Function}

Serum bilirubin was normal in all except one child with sickle-cell disease in whom it was $1.9 \mathrm{mg} . / 100 \mathrm{ml}$. (normal range $<1 \mathrm{mg} . / 100 \mathrm{ml}$.). Serum aspartate and alanine aminotransferase were normal in all except one child, in whom they were slightly raised (normal range $<40$ units). Serum alkaline phosphatase was higher than the normal adult range in all except 11 children (mean 19.3, range 7-36 King-Armstrong units). Levels in normal children are usually elevated when compared with the adult range of 3-13 units (Varley, 1962).

\section{Discussion}

The only permanent abnormality in the 50 liver biopsy specimens was "stellate" fibrosis in six; in none of these was there 
a disturbance in the normal liver architecture. It is impossible from this study to relate this fibrosis to the past malnutrition. There was no evidence of cirrhosis, and all biopsy specimens were adequate for histological assessment. The cause of the focal variation in nuclear size in the parenchymal cells is unknown, but was less marked in the present series than in a random group of adult Ugandan African inpatients studied at the Mulago Hospital (Cook and Hutt, 1967). It can be a non-specific result of increased cell turnover (Popper and Schaffner, 1957), and also occurs in malnutrition, as deficiency of riboflavine and pyridoxine has been shown to produce gross nuclear irregularity in the hepatic parenchymal cells of the baboon (Foy et al., 1966). There is, however, no good reason to incriminate current malnutrition in the present study.

Apart from slight portal changes, the only consistent difference between the biopsy specimens in this follow-up study and those from the European children was in the reticuloendothelial components, especially the Kupffer cells. These changes are probably due to parasitic diseases, especially malaria. Malarial pigment was found in the Kupffer cells and/or portal areas in approximately $60 \%$ of the biopsy specimens, of whom less than half had splenomegaly and only eight had a positive or very positive malarial antibody titre. In three children there was an association between splenomegaly, increased sinusoidal lymphocytes, and a strongly positive malarial antibody titre. Gebbie et al. (1964) have reported a significant association between gross splenomegaly, an increase in sinusoidal lymphocytes, and a strongly positive malarial antibody titre, but without malarial pigment in the liver biopsy specimen; this probably represents an unusual reticuloendothelial reaction to chronic malarial infection.

This study, despite the fact that at a follow-up examination some of the children were still malnourished and others had evidence of anaemia, malaria, tuberculosis, and other infections, demonstrates that, apart from a few differences which are presumably reversible, liver histology of most Ugandan children after kwashiorkor is very similar to that of European children who have not lived in the tropics.

Despite the widespread belief in many tropical areas that infant malnutrition may account for cases of cirrhosis in later life, the present study in tropical Africa confirms the view of most other workers (Higginson et al., 1957 ; Suckling and Campbell, 1957 ; Bras, 1961) that treated kwashiorkor does not predispose to permanent liver damage. The possibility that prolonged untreated kwashiorkor may proceed to cirrhosis (Davies, 1948; Ramalingaswami, 1964) cannot be eliminated by the present study. Most of the children studied had, however, had severe kwashiorkor, and in some cases this had probably been present for a year or more. Only one biopsy specimen still contained an excess of fat in the parenchymal cells. Davies (1951) has suggested that the development of cirrhosis may be a delayed phenomenon and takes place only after the disappearance of fat in kwashiorkor. While this is possible, the absence of any evidence of cirrhosis in six biopsy specimens taken 10 years or more after the treatment of severe or very severe kwashiorkor indicates that progression to cirrhosis must be a rare occurrence. Since it is not possible to obtain an accurate estimate of either the frequency of recovery from untreated kwashiorkor or the overall incidence of adult cirrhosis in Uganda, it must be questioned whether a large enough number of cases has been studied to rule out progressive liver disease in some children after kwashiorkor.

The results of the present investigation apply only to Uganda. There is evidence that liver pathology in kwashiorkor may vary in different areas. In New Guinea, atrophy and vacuolation of parenchymal cells is more obvious than the fatty infiltration (Venkatachalam and Ivinskis, 1957 ; Bailey, 1966) which is so consistent a finding in Uganda.
High serum alkaline phosphatase levels were found in approximately $75 \%$ of the children, owing presumably to increased osteoblastic activity in bone.

The good general nutritional status of most of the children here studied after recovery from kwashiorkor, but while continuing to live in the poor socio-economic environment in which they developed kwashiorkor, is striking (Suckling and Campbell, 1957).

\section{Summary}

Hepatic histology and biochemical tests of liver function have been studied in 50 Ugandan children, 4.0 to 11.3 (mean 7.0) years after admission to hospital with kwashiorkor. The kwashiorkor had been severe in 32 of the children.

Liver biopsy specimens all showed slight differences when compared with biopsies from six European children who had never lived in tropical areas. Six patients had some "stellate" fibrosis radiating from the portal areas, and in one case there was an excess of fat in the parenchymal cells, but in none was there any evidence of cirrhosis or progressive liver disease.

The liver-function tests gave normal results in most. Serum alkaline phosphatase was elevated, compared with adult levels, in 39 of the children.

There is no evidence from this study that progressive liver disease and cirrhosis are long-term sequelae of treated kwashiorkor in Uganda. The possibility that cirrhosis may follow prolonged untreated kwashiorkor has not been eliminated.

We thank Mr. Y. M. Semindi for finding the children for this investigation, and Drs. R. A. Tozer and N. J. Mody for the haematology and liver-function tests respectively. Mr. G. R. Howells was responsible for the plasma proteins and biochemical tests of nutritional status, and Dr. D. E. Wykoff for the fluorescent malarial antibody reactions. Dr. P. J. Scheuer, of the Royal Free Hospital, London, sent us the liver biopsy specimens from the six European children that were used as controls. We are grateful to Professor R. A. McCance, F.R.S., for valuable discussion concerning the manuscript.

\section{REFERENCES}

Bailey, K. V. (1966). Med. 7. Aust., 1, 572.

Bras, G. (1961) Fed. Proc., 20, Suppl. No. 7, p. 353

Brock, J. F. (1966). Ann. intern. Med., 65, 877 .

Burgess, A. P., and Burgess, H. J. L. (1964). Hum. Biol., 36, 177.

Cook, G. C. (1967a). Nature (Lond.). In press. (1967b). Awaiting publication and Hutt, M. S. R. (1967). Unpublished. and Lee, F. D. (1966). Lancet, 2, 1263

Davies, J. N. P. (1948). Ibid., 1, 317.

- (1951). In Liver Injury, edited by F. W. Hoffbauer, pp. 151-205. New York.

Dean, R. F. A. (1960). F. Pediat., 56, 675

Foy, H., Gillman, T., Kondi, A., and Preston, J. K. (1966). Nature (Lond.), 212, 150 .'

Gebbie, D. A. M., Hamilton, P. J. S., Hutt, M. S. R., Marsden, P. D., Voller, A., and Wilks, N. E. (1964). Lancet, $2,392$.

Gillman, J., and Gillman, T. (1951). Perspectives in Human Malnutrition, pp. 214-245. New York.

Higginson, J., Grobbelaar, B. G., and Walker, A. R. P. (1957). Amer. F. Path., 33, 29.

Menghini, G. (1958). Gastroenterology, 35, 190

Popper, H., and Schaffner, F. (1957). Liver: Structure and Function, pp. 87-93. London.

Ramalingaswami, V. (1964). Nature (Lond.), 201, 546.

Suckling, P. V., and Campbell, J. A. H. (1957). f. trop. Pediat., 2, 173. Trowell, H. C., Davies, J. N. P., and Dean, R. F. A. (1954). Kwashiorkor, pp. 128-144. London.

Varley, H. (1962). Practical Clinical Biochemistry, 3rd ed., p. 385. London.

Venkatachalam, P. S., and Ivinskis, V. (1957). Med. f. Aust., 1, 275. Voller, A., and Bray, R. S. (1962). Proc. Soc. exp. Biol. (N.Y.), 110, 907 .

Waterlow, J. C., and Bras, G. (1957). Brit. med. Bull., 13, 107.

Whitehead, R. G. (1964). Lancet, 1, 250.

(1965). Ibid., 2, 567. 